\title{
Ekspresi dan Pathway Analisis Gen CD14 dan IL10 pada Sapi Perah yang Terinfeksi Mastitis Subklinis
}

\author{
Expression and Pathway Analysis of Gene CD14 and IL10 in Infected Dairy with Subclinical Mastitis
}

\author{
Widiono $^{1)}$ A. Gunawan ${ }^{2)}$ C. Sumantri ${ }^{2)}$ \& N. D. Yanthi ${ }^{3)}$ \\ ${ }^{1)}$ Program Studi Ilmu Produksi dan Teknologi Peternakan, Sekolah Pascasarjana, IPB \\ ${ }^{2}$ Departemen Ilmu Produksi dan Teknologi Peternakan, Fakultas Peternakan, IPB \\ ${ }^{3)}$ Pusat Penelitian Bioteknologi, Lembaga Ilmu dan Pengetahuan Indonesia \\ Email koresponden author: widiono09@gmail.com
}

\begin{abstract}
Mastitis is an inflammation of internal udder tissue caused by bacteria, it decrease milk production both in quality and quantity. This study was aimed to identify expression and pathway analysis of gene CD14 and IL10 as resistance genes in dairy infected with subclinical mastitis. Sample were taken from milk and blood 10 healthy dairy and 10 dairy containing subclinical mastitis used for CMT and RNA isolation used for gene expression analysis. The result showed that expression in healthy dairy CD14 gene had a higher expression $(\mathrm{P}<0.05)$. In contrast the IL10 gene had a high expression in infected dairy with subclinical mastitis $(\mathbf{P}<\mathbf{0 . 0 5})$. CD14 was an early signal receptor that activates a complex nonspecific immune response to induce various immune characteristics such as the production of inflammatory cytokines and chemokines, the production of antimicrobial peptides and so on destroy pathogens. The high expression of IL10 in infected dairy with subclinical mastitis suggested that immune responses were not functioning properly considered due to inhibiton of cytokine transduction signals by excessive production of IL10.
\end{abstract}

Keywords: subclinical mastitis, CD14 and IL10, gene expression

\section{PENDAHULUAN}

Salah satu komoditas pangan dari subsektor peternakan yang senantiasa diperlukan masyarakat adalah susu yang dihasilkan oleh sapi perah. Pada tahun 2017, konsumsi domestik susu sapi Indonesia sebesar 1,01 juta ton, tahun berikutnya naik menjadi 1,05 juta ton. Tahun 2019 diprediksi kembali meningkat 4,09\% menjadi sebesar 1,1 juta ton, dan tahun 2020 diprediksi meningkat menjadi 1,14 juta ton. Pada tahun 2016 produksi susu sapi Indonesia diperkirakan mencapai 852.951 ton atau meningkat 2,13\% dibandingkan produksi satu tahun sebelumnya. Pada tahun 2017, diperkirakan naik sebesar 88,89 ribu ton atau 4,04\% dari tahun sebelumnya. Tahun 2018, 2019, dan 2020 diproyeksikan produksi susu sapi akan kembali meningkat menjadi 973,64 ribu ton, 1,01 juta ton, dan 1,04 juta ton atau tumbuh masing-masing sebesar 3,38\%, 3,33\%, dan 3,28\% dari tahun sebelumnya (Kementan 2016).

Data menunjukan bahwa kebutuhan susu dalam negeri selalu mengalami peningkatan seiring dengan pertambahan jumlah penduduk, peningkatan pendapatan serta kesadaran masyarakat terhadap gizi dan kesehatan, namun masih ada kesenjangan antara angka produksi susu dalam negeri dengan peningkatan jumlah kebutuhannya. Hal tersebut menunjukan kecukupan ketersediaan dan stabilitas produksi susu dalam negeri masih mengalami banyak kendala dari segi kualitas dan kuantitasnya. Salah satu faktor yang menyebabkan produksi susu nasional sulit untuk meningkat secara signifikan adalah mudahnya sapisapi di Indonesia terserang dan terjangkit penyakit mastitis. Mastitis merupakan penyakit yang dapat menimbulkan kerugian ekonomi pada ternak sapi perah karena menurunkan produksi susu baik secara kualitas maupun kuantitas (Schroeder 2010). Mastitis merupakan peradangan pada jaringan internal ambing (Sudarwanto 2009), mastitis bisa disebabkan oleh kuman patogen (infeksius) seperti bakteri (Anri 2008). Bakteri penyebab mastitis diantaranya Staphylococcus aureus, Streptococcus agalactiae, Streptococcus dysgalactiae, Streptococcus uberis (Quinn et al 2002).

Diagnosis mastitis subklinis dapat dilakukan dengan melakukan penghitungan jumlah sel somatik (JSS) dalam susu. Bakteri umumnya bertahan pada jaringan dalam beberapa minggu atau bulan sebagai penyebab mastitis subklinis (Bramley 1991). Hurley dan Morin (2000), menjelaskan bahwa peradangan pada ambing diawali dengan masuknya bakteri ke dalam ambing yang dilanjutkan dengan multiplikasi. Pada respon pertama, pembuluh darah ambing akan mengalami vasodilatasi dan terjadi peningkatan aliran darah pada ambing. Permeabilitas pembuluh darah meningkat disertai dengan pembentukan produk - produk inflamasi, seperti prostaglandin, leukotrine, protease dan metabolit oksigen toksik yang 
dapat meningkatkan permeabilitas kapiler ambing. Adanya filtrasi cairan ke jaringan menyebabkan kebengkakan pada ambing. Pada saat proses tersebut terjadi diapedesis, selsel fagosit (PMN dan makrofag) keluar dari pembuluh darah menuju jaringan yang terinfeksi dilanjutkan dengan fagositosis dan penghancuran bakteri.

Respon imun melibatkan proses metabolisme yang terdiri dari rangkaian reaksi biokimia yang dikatalisis oleh enzim tertentu dan ditentukan oleh ekspresi gen yang berfungsi mensintesis enzim (protein) tersebut. Mastitis sebagai sifat genetik yang kompleks, resistensi terhadap mastitis cenderung dikendalikan oleh banyak gen. Beberapa studi mengkaji berbagai ekspresi gen dalam mastitis seperti IL4, IL6, IL8, dan TNF $\alpha$ dengan hasil yang tidak signifikan. Studi lain menunjukan ekspresi TLR2 yang tinggi pada sapi mastitis (Fonseca et al. 2009). Gen lain yang diduga berperan dalam proses imun/ketahanan mastitis adalah CD14 dan IL10.

Posisi gen CD14 pada ternak sapi terletak di kromosom 7 yang terdiri atas 2 ekson dan 1 intron (www. ncbi.mlm.nih.gov). Gen CD14 memiliki peran penting pada infeksi jaringan ambing yang disebabkan oleh bakteri gram negatif (Huang et al. 2016). Cluster Diferensiasi 14 (CD14) terletak di monosit, makrofag, neutrofil, dan sel plasma. CD14 mengikat lipopolisakarida (LPS) pada permukaan bakteri gram negatif, dan peptidoglikan (PGN) dan asam lipoteikoat (LTA) pada permukaan bakteri gram positif. CD14-LPS kompleks akan merekrut PMN ke situs peradangan dan kemudian mengurangi kerusakan ambing yang disebabkan oleh endotoksin (Sladek dan Rysanek 2006).

IL10 terletak di kromosom 16 yang terdiri atas 5 ekson dan 4 intron (www.ncbi.mlm.nih.gov). IL10 diketahui sebagai antagonis sitokin bahwa protein tersebut dapat berikatan dengan reseptor sitokin tetapi tidak dapat mengaktifkan sel dan mencegah aktivitas biologis sitokin (Baratawidjaja dan Rengganis 2014). IL10 merupakan sitokin antiinflamasi yang dapat menghambat sel-sel pembunuh (Barral et al. 1995). Sel susu hewan yang terpapar oleh mastitis kronis yang disebabkan oleh Staphylococcus aureus menunjukan ekspresi IL10 yang lebih tinggi dibandingkan dengan sapi sehat (Riollet et al 2001).

Pengendalian mastitis dengan pendekatan secara genetik dinilai sebagai strategi jangka panjang terbaik walaupun saat ini belum banyak penelitian yang berkaitan dengan hal tersebut. Kajian ekspresi dan pathway analisis gen CD14 dan IL10 pada sapi perah yang sehat dan pada sapi perah yang terinfeksi mastitis subklinis sangat diperlukan untuk melihat proses pembentukan pertahanan tubuh (fungsi imunitas tubuh), selanjutnya kehadiran gen tersebut dapat digunakan sebagai penciri genetik untuk seleksi ternak dalam mengatasi mastitis.

\section{MATERI DAN METODE}

\section{Waktu dan Tempat Penelitian}

Penelitian dilakukan pada bulan Januari 2018. Koleksi sampel susu dan darah dilakukan di peternakan PT UPBS Pangalengan, sedangkan isolasi RNA dan analisa ekspresi gen dilakukan di Laboratorium Kesehatan Hewan - Pusat Penelitian Bioteknologi Peternakan LIPI Cibinong.

\section{Prosedur Penelitian \\ California Mastitis Test}

Sampel susu digunakan untuk pengujian california mastitis test sebagai data fenotipik. Susu diambil dari setiap kuartir ambing sapi sebanyak $2 \mathrm{~mL}$ yang ditempatkan di paddle lalu direaksikan dengan reagen california mastitis test sebanyak $2 \mathrm{~mL}$. Campuran tersebut digoyang secara horizontal selama 10-15 detik. Reaksi diamati ada atau tidaknya perubahan kekentalan susu, kemudian kekentalan susu ditentukan berdasarkan skoring CMT seperti pada Tabel 2. Nilai CMT masing-masing sapi diambil dari ratarata kuartir per individu. Kuartitr sapi dengan jumlah sel somatik 0-200.000 per mililiter diartikan sehat, jumlah sel somatik 150.000-500.000 per $\mathrm{mL}$ diartikan sehat namun ada kemungkinan akan terinfeksi, dan junah sel somatik $>$ 400.000 per $\mathrm{mL}$ diartikan terinfeksi mastitis subklinis (lihat Tabel.1)

\section{Analisa Ekspresi Gen}

Analisa ekspresi gen dilakukan dengan teknik Real Time PCR. Hasil isolasi RNA digunakan untuk transkripsi balik cDNA. cDNA tersebut disintesis menggunakan MyTaq ${ }^{\mathrm{TM}}$ One-Step $R T-P C R$ Kit Bioline. Setiap reaksi terkandung reagent $2 \mathrm{x}$ MyTaq One-StepMix, Forward Primer $(10 \mu \mathrm{M})$, Reverse Primer $(10 \mu \mathrm{M})$, Reverse transcriptase, RiboSafe RNase Inhibitor, DEPC-H2O, dan template RNA dengan total volume $20 \mu \mathrm{l}$ per sumur. Gen primer spesifik untuk RT-PCR dirancang dengan menggunakan software PCR primer stats. Pada proses RT PCR, setiap reagent yang direaksikan dimasukan dalam 48-well plate microtiter. RTPCR dilakukan dengan program berikut: Reverse transcript $45^{\circ} \mathrm{C}$ selama 10 menit, Polymerase activation $95^{\circ} \mathrm{C}$ selama 2 menit, PCR Cycling $95^{\circ} \mathrm{C}$ selama 5 detik dan $58^{\circ} \mathrm{C}$ selama 10 detik dengan total 40 siklus, Melt Curve selama $95^{\circ} \mathrm{C}$ selama 15 detik; $55^{\circ} \mathrm{C}$ selama 15 detik dan $95{ }^{\circ} \mathrm{C}$ selama 15 detik dengan menggunakan Illumina Eco Real Time PCR. Semua sampel dianalisis dua kali (replikasi teknis) dan rata-rata dari nilai-nilai Ct selanjutnya digunakan untuk mengukur tingkat ekspresi. Mean dari gen housekeeping GAPDH digunakan untuk normalisasi gen target. Nilai delta $\mathrm{Ct}(\Delta \mathrm{Ct})$ dihitung sebagai perbedaan antara gen target dan rata-rata dari gen referensi/housekeeping $(\Delta \mathrm{Ct}=$ CttargetCthousekeeping) (Silver et al. 2003).

\section{Analisa Data}

Hasil akhir dianalisa dengan metode statistik Uji-T untuk melihat signifikansi ekspresi gen antara sapi yang sehat dan sapi yang terinfeksi mastitis. Model matematis dirumuskan sebagai berikut :

$$
t-t e s t=\frac{\bar{X}_{1}-\bar{X}_{2}}{\sqrt{\left(\frac{S D_{1}^{2}}{N_{1}-1}\right)+\left(\frac{S D_{2}^{2}}{N_{2}-1}\right)}}
$$


Tabel 1 Penilaian uji CMT

\begin{tabular}{lccc}
\hline Pengamatan & Nilai CMT & Jumlah Sel Somatik & Status \\
\hline Tidak ada pengentalan (-) & 0 & $0-200.000$ & Sehat \\
Sedikit pengentalan (+) & 0 & $150.000-500.000$ & Sehat \\
& & & (kemungkinan terinfeksi) \\
Ada pengentalan $(++)$ & 1 & $400.000-1.500 .000$ & Mastitis Subkinis \\
Pengentalan solid (+++) & 2 & $800.000-5.000 .000$ & Mastitis Subkinis \\
Pengentalan sangat solid $(++++)$ & 3 & $>5.000 .000$ & Mastitis Subkinis \\
\hline
\end{tabular}

Sumber : Radostis 2000

Tabel 2 Sekuens primer gen CD14, IL10 dan GAPDH

\begin{tabular}{llcc}
\hline Gen & Sekuens Primer & bp & Access Number \\
\hline CD 14 & F: 5'-CTC AGC GTG CTT GAT CTC AG-3' & 107 & NM_174008.1 \\
& R: 5'-CAG GGT CCA GAA AGG GAT TT-3' & & \\
IL 10 & F: 5'-CAT CGA TTT CTT CCC TGT GAA-3' & 74 & NM_174088.1 \\
& R: 5'-TCT TGG AGC TTA TTA AAG GCA TTC-3' & & NM_001034034.2 \\
& FAPDH \\
\hline
\end{tabular}

Sumber :www. ncbi.mlm.nih.gov

Keterangan :

$\bar{X}_{1}=$ Rata-rata ekspresi mRNA pada sapi sehat

$\bar{X}_{2}=$ Rata-rata ekspresi mRNA pada sapi mastitis subklinis

$\mathrm{SD}_{1}^{2}=$ Nilai varian ekspresi mRNA pada sapi sehat

$\mathrm{SD}_{2}^{2}=$ Nilai varian ekspresi mRNA pada sapi mastitis subklinis

$N_{1}=$ Jumlah individu pada sapi sehat

$N_{2}=$ Jumlah individu pada sapi mastitis subklinis

\section{Pathway Analisis}

Selanjutnya untuk analisa jalur sinyal transduksi masing masing gen didapatkan dari sistem bioinformatik kegg pathway pada www.genome.jp/kegg/pathway. html. Akses database entry untuk CD14 dengan nomor map04620, dan untuk database entry IL10 dengan nomor map04060.

\section{HASIL DAN PEMBAHASAN}

\section{Hasil Uji CMT}

Nilai CMT dari hasil uji CMT digunakan untuk membedakan sapi sehat dengan sapi yang terinfeksi mastitis subklinis. Nilai CMT berhubungan dengan jumlah sel somatik yang terkandung dalam susu. Semakin tinggi nilai CMT, semakin tinggi jumlah sel somatik yang ditunjukan dengan viskosistas reaksi yang semakin tinggi (Herlina et al. 2015). Jumlah sel somatik tersebut dijadikan sebagai acuan untuk menjustifikasi sapi yang terinfeksi mastitis subklinis.

Pada Tabel 3 menunjukan 10 ekor sapi sehat yang diamati susunya memiliki nilai CMT 0 artinya sapi tersebut benar dalam keadaan sehat, walaupun masih ada variasi pada masing-masing kuartir sapi yang menunjukan tanda (-) yaitu berupa penampilan susu yang tidak disertai perubahan kekentalan, sedangkan tanda $(+)$ menunjukan penampakan susu yang diamati terjadi perubahan kekentalan namun terlihat samar. Tanda (-)/negative ekuivalen dengan jumlah sel somatik sekitar 0-200.000 per mililiter dengan interpretasi kuartir sehat, sedangkan tanda $(+)$ /trace ekuivalen dengan jumlah sel somatik sekitar 150.000-500.000 per mililiter dengan interpretasi kuartir sehat namun terindikasi akan terinfeksi oleh mastitis subklinis (Radostis et al. 2000).

Tabel 4 menunjukan seluruh sapi yang diduga terinfeksi mastitis subklinis memiliki nilai CMT 1-2, artinya sapi-sapi tersebut mengindikasikan telah terinfeksi oleh mastitis subklinis. Hasil pengamatan menunjukan kondisi susu dari masing-masing kuartir pada sapi-sapi tersebut bervariasi yaitu $(++)$ yaitu penampilan susu yang diamati terjadi perubahan kekentalan namun tidak membentuk gel, tanda $(+++)$ menunjukan adanya perubahan kekentalan dan membentuk gel yang samar/tipis, sedangkan tanda $(++++)$ menunjukan perubahan kekentalan solid yang membentuk gel. Tanda $(++)$ ekuivalen dengan jumah sel somatik 400.000-1.500.000 per mililiter dengan interpretasi terinfeksi mastitis subklinis, tanda $(+++)$ ekuivalen dengan jumah sel somatik 800.000-5.000.000 per mililiter dengan interpretasi terinfeksi mastitis subklinis, dan Tanda $(++++)$ ekuivalen dengan jumah sel somatik $>5.000 .000$ per mililiter dengan interpretasi terinfeksi mastitis subklinis (Radostis et al. 2000).

Mastitis subklinis adalah peradangan ambing yang tidak menunjukkan gejala klinis tetapi pada pemeriksaan susu secara mikroskopik terdapat peningkatan jumlah sel somatik lebih besar dari 400.000 sel setiap $\mathrm{mL}$ susu (Sudarwanto et al. 2006). Jumlah sel somatik yang tinggi menunjukkan terjadinya infeksi yang menurunkan kualitas 
Tabel 3 Fenotipe berdasarkan nilai CMT sapi sehat

\begin{tabular}{|c|c|c|c|c|c|c|c|c|}
\hline \multirow[t]{3}{*}{ No } & \multirow[t]{3}{*}{ Sapi } & \multicolumn{4}{|c|}{ Perubahan Kekentalan } & \multirow[t]{3}{*}{ Nilai CMT } & \multirow[t]{3}{*}{ Jumlah Sel Somatik } & \multirow[t]{3}{*}{ Status } \\
\hline & & \multicolumn{2}{|c|}{ Kuartir depan } & \multicolumn{2}{|c|}{ Kuartir belakang } & & & \\
\hline & & kiri & kanan & kiri & kanan & & & \\
\hline 1 & H1 & + & - & + & - & 0 & $150.000-500.000$ & Sehat \\
\hline 2 & $\mathrm{H} 2$ & - & + & + & - & 0 & $150.000-500.000$ & Sehat \\
\hline 3 & $\mathrm{H} 3$ & + & - & - & - & 0 & $150.000-500.000$ & Sehat \\
\hline 4 & $\mathrm{H} 4$ & - & + & + & - & 0 & $150.000-500.000$ & Sehat \\
\hline 5 & H5 & - & - & - & + & 0 & $150.000-500.000$ & Sehat \\
\hline 6 & H6 & - & + & - & - & 0 & $150.000-500.000$ & Sehat \\
\hline 7 & $\mathrm{H} 7$ & + & - & - & + & 0 & $150.000-500.000$ & Sehat \\
\hline 8 & $\mathrm{H} 8$ & - & + & - & - & 0 & $150.000-500.000$ & Sehat \\
\hline 9 & H9 & - & - & - & + & 0 & $150.000-500.000$ & Sehat \\
\hline 10 & $\mathrm{H} 10$ & - & - & - & + & 0 & $150.000-500.000$ & Sehat \\
\hline
\end{tabular}

Tabel 4 Fenotipe berdasarkan nilai CMT sapi mastitis subklinis

\begin{tabular}{|c|c|c|c|c|c|c|c|c|}
\hline \multirow[t]{3}{*}{ No } & \multirow[t]{3}{*}{ Sapi } & \multicolumn{4}{|c|}{ Perubahan Kekentalan } & \multirow[t]{3}{*}{ Nilai CMT } & \multirow[t]{3}{*}{ Jumlah Sel Somatik } & \multirow[t]{3}{*}{ Status } \\
\hline & & \multicolumn{2}{|c|}{ Kuartir depan } & \multicolumn{2}{|c|}{ Kuartir belakang } & & & \\
\hline & & kiri & kanan & kiri & kanan & & & \\
\hline 1 & M1 & +++ & ++ & +++ & ++++ & 2 & $800.000-5.000 .000$ & Mastitis Subklinis \\
\hline 2 & M2 & +++ & +++ & +++ & +++ & 2 & $800.000-5.000 .000$ & Mastitis Subklinis \\
\hline 3 & M3 & +++ & ++++ & ++ & +++ & 2 & $800.000-5.000 .000$ & Mastitis Subklinis \\
\hline 4 & M4 & ++++ & ++ & +++ & +++ & 2 & $800.000-5.000 .000$ & Mastitis Subklinis \\
\hline 5 & M5 & ++ & +++ & - & ++ & 1 & $400.000-1.500 .000$ & Mastitis Subklinis \\
\hline 6 & M6 & ++ & +++ & ++ & - & 1 & $400.000-1.500 .000$ & Mastitis Subklinis \\
\hline 7 & M7 & ++ & ++++ & +++ & +++ & 2 & $800.000-5.000 .000$ & Mastitis Subklinis \\
\hline 8 & M8 & ++ & - & +++ & ++ & 1 & $400.000-1.500 .000$ & Mastitis Subklinis \\
\hline 9 & M9 & ++ & - & +++ & ++ & 1 & $400.000-1.500 .000$ & Mastitis Subklinis \\
\hline 10 & M10 & ++ & +++ & +++ & ++++ & 2 & $800.000-5.000 .000$ & Mastitis Subklinis \\
\hline
\end{tabular}

susu. Parameter yang paling mendasar untuk mendeteksi mastitis subklinis adalah jumlah sel somatik (Rice dan Bodman 1997). Sel somatik dalam susu merupakan kumpulan sel yang terdiri atas kelompok leukosit (sel limfosit, neutrofil, makrofag, eosinofi dan basofil), runtuhan sel epitel jaringan ambing dan lain-lain. Sel epitel merupakan bagian dari fungsi tubuh yang dilepaskan dan diperbaiki dalam proses tubuh yang normal, sedangkan leukosit merupakan komponen kekebalan tubuh terhadap keberadaan benda asing. Terdapat tiga jenis sel somatik yang terdapat dalam susu yaitu sel epitel, Makrofag dan polimorfonuklear netrofil (PMN) (Lindmark et al. 2006).

\section{Ekspresi Gen CD14 dan IL10}

Ekspresi gen mRNA pada sapi sehat dan sapi yang terinfeksi mastitis subklinis dilakukan dengan teknik kuantitatif real time PCR.. Hasil analisis ekspresi dari gen mRNA CD14 dan IL10 pada sapi yang sehat dan sapi yang terinfeksi mastitis subklinis menunjukan perbedaan (Gambar 1 dan Gambar 2). Ekspresi mRNa gen CD14 menunjukan ekspresi yang tinggi $(\mathrm{P}<0,05)$ pada sapi yang sehat. Ekspresi mRNA gen IL10 menunjukan ekspresi yang tinggi $(\mathrm{P}<0,05)$ pada sapi yang terinfeksi mastitis subklinis. Penelitian lain melaporkan ekspresi CD14 yang tinggi menunjukan gen CD14 mengikat lipopolisakarida (LPS) pada permukaan bakteri gram negatif, dan peptidoglikan (PGN) dan asam lipoteikoat (LTA) pada permukaan bakteri gram positif. CD14-LPS kompleks akan merekrut PMN ke situs peradangan kemudian mengurangi kerusakan ambing yang disebabkan oleh endotoksin (Sladek dan Rysanek 2006). Penelitian lain melaporkan sel susu dengan mastitis kronis yang disebabkan oleh Staphylococcus aureus menunjukan ekspresi IL10 yang lebih tinggi dibandingkan dengan sapi sehat (Riollet et al. 2001).

\section{Pathway Analisis CD14 dan IL10}

Jumlah sel somatik sapi sehat antara 150.000500.000 sel per milimeter, menunjukan sapi-sapi tersebut diserang oleh bakteri penyebab mastitis. Diduga pada saat terjadi serangan patogen respon imun nonspesifik bekerja dengan baik sehingga sapi tersebut masih dalam keadaan sehat. Hal tersebut ditunjukan oleh tingginya ekspresi CD14 pada sapi sehat, bahwa CD14 merupakan reseptor pemberi sinyal awal yang mengaktifkan kompleks respon imun nonspesifik untuk menghasilkan induksi berbagai ciri imunitas seperti produksi sitokin inflamasi dan kemokin, produksi peptida antimikrobial dan sebagainya untuk menghancurkan patogen. 


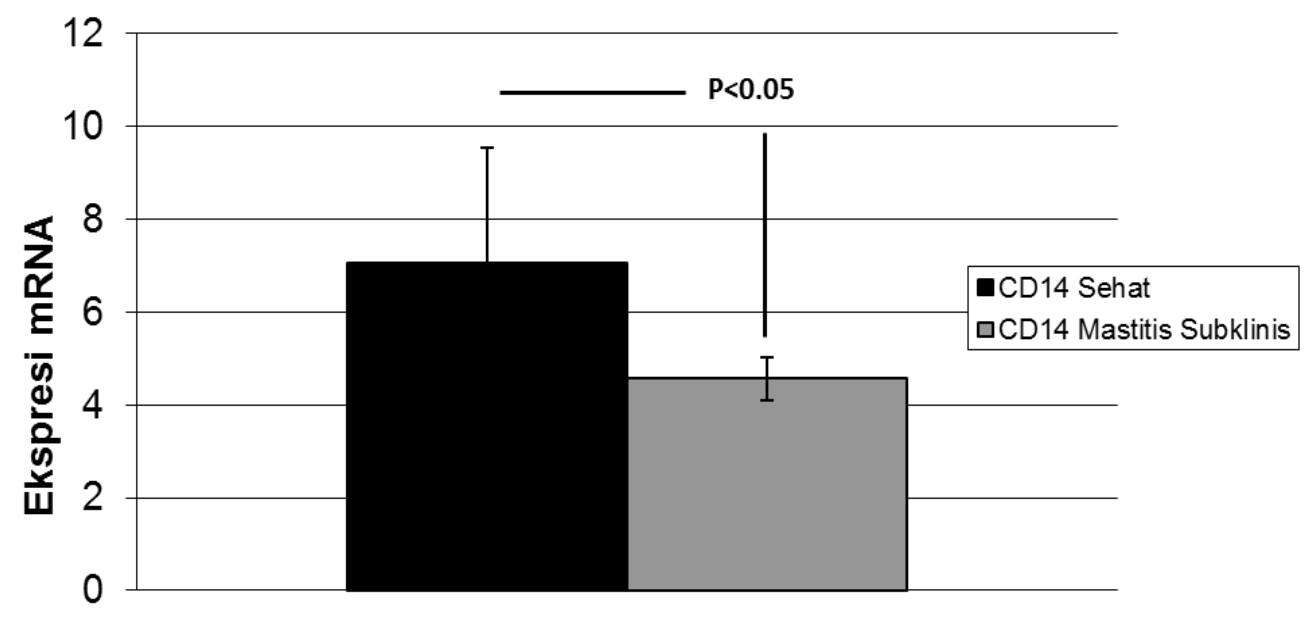

Gambar 1. Ekspresi gen CD14

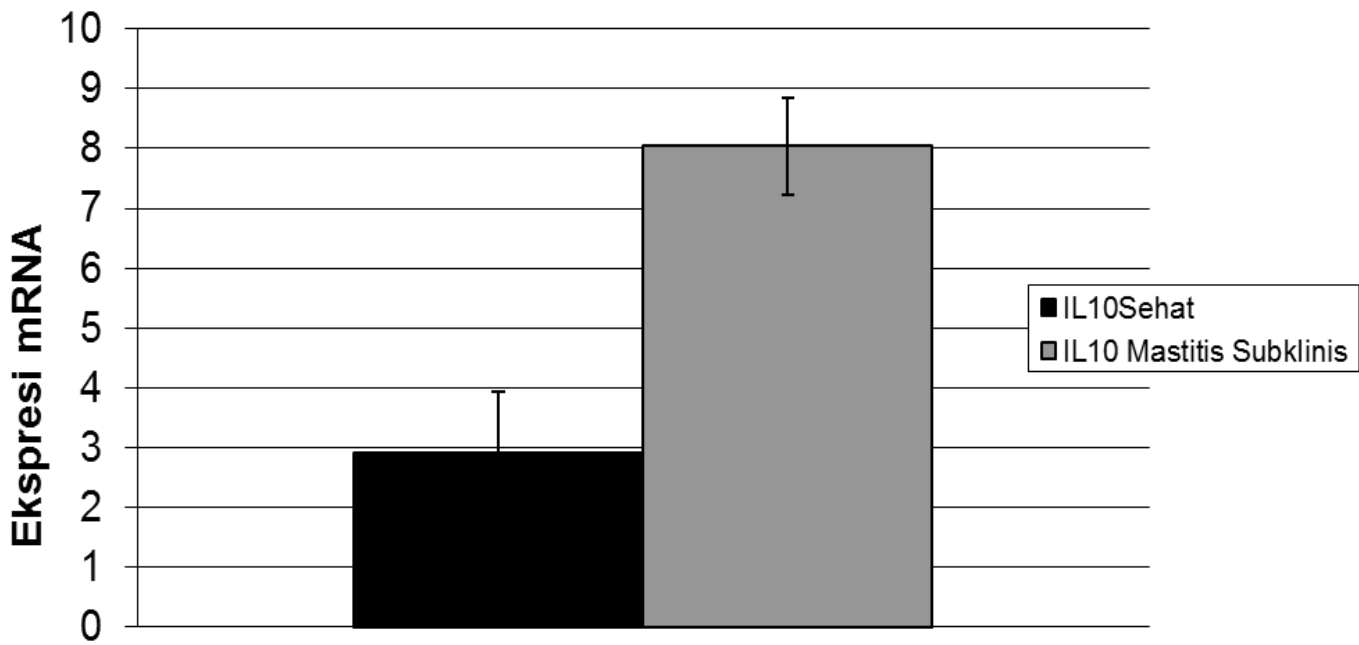

Gambar 2. Ekspresi gen IL10

Analisis KEGG Pathway menunjukan bahwa posisi CD14 sebagai reseptor berada dalam jalur transduksi sinyal TLR yang khas (Gambar 3). Sebagai reseptor CD14 akan mengikat lipopolisakarida (LPS) pada permukaan bakteri gram negatif, dan peptidoglikan (PGN) serta asam lipoteikoat (LTA) pada permukaan bakteri gram positif (Sladek dan Rysanek 2006). Baratawidjaja dan Rengganis 2014, menjelaskan bahwa ikatan ligan tersebut memacu penggabungan My88 dengan domain TIR dan pembentukan kompleks IRAK1/IRAK4. Selanjutnya IRAK4 akan memfosforilasi IRAK1 dan menghasilkan tempat ikatan untuk TRAF6. Kompleks IRAK1-TRAF6 terpecah dan mengaktifkan kompleks protein kinase TAK1. TAK1 yang sudah diaktifkan akan menghasilkan 2 sinyal transduksi yang berbeda.

Selanjutnya TAK1 memfosforilasi IKK untuk mengaktifkan jalur NFkB, IKK lalu memfosforilasi IkB sehingga terjadi pelepasan NFkB. TAK1 juga memfosforilasi dan mengaktifkan suatu komponen dari jalur MAPK. NFkB yang dilepas bertranslokasi dari sitoplasma ke nukleus menjadi aktivator transkripsi gen NFkB dependen, sedangkan kaskade MAPK menyebabkan translokasi dari sitoplasma ke nukleus dan mengaktifkan transkripsi gen
MAPK dependen (Baratawidjaja dan Rengganis 2014). Shaulin dan Karin (2002) menambahkan bahwa kelompok MAPK akan memfosforilasi dan mengaktifkan faktor transkripsi AP-1, sebuah dimer Basic Region Leucine Zipper (BZIP) protein dari Jun, Fos, ATF dan Maf subfamili. Diantara itu, keterlibatan c-Jun memiliki peran sentral pada respons inflamasi dalam pensinyalan TLR. Lalu sinyalsinyal tersebut akan mengaktifkan sitokin inflamasi.

Sapi yang terinfeksi mastitis subklinis menunjukan jumlah sel somatik 400.000-5.000.000 sel per milimeter. Jumlah tersebut menunjukan kadar sel somatik yang sangat tinggi dengan interpretasi sapi sudah terinfeksi oleh bakteri penyebab mastitis. Hal tersebut terjadi diduga karena respon imun dari sapi yang terkena infeksi patogen mastitis tidak bekerja dengan baik. Hal tersebut ditunjukan oleh tingginya ekspresi IL10 pada sapi yang sakit, bahwa IL10 merupakan inhibitor makrofag dan sel dendritik yang berperan mengontrol reaksi imun non spesifik dan selular (Baratawidjaja dan Rengganis 2014). Artinya jika ekspresi IL10 tinggi maka telah terjadi penghambatan sintesis dari beberapa gen sitokin.

Analisis KEGG Pathway menunjukan reseptor kompleks IL10 pada sel terdiri dari empat transmembran 


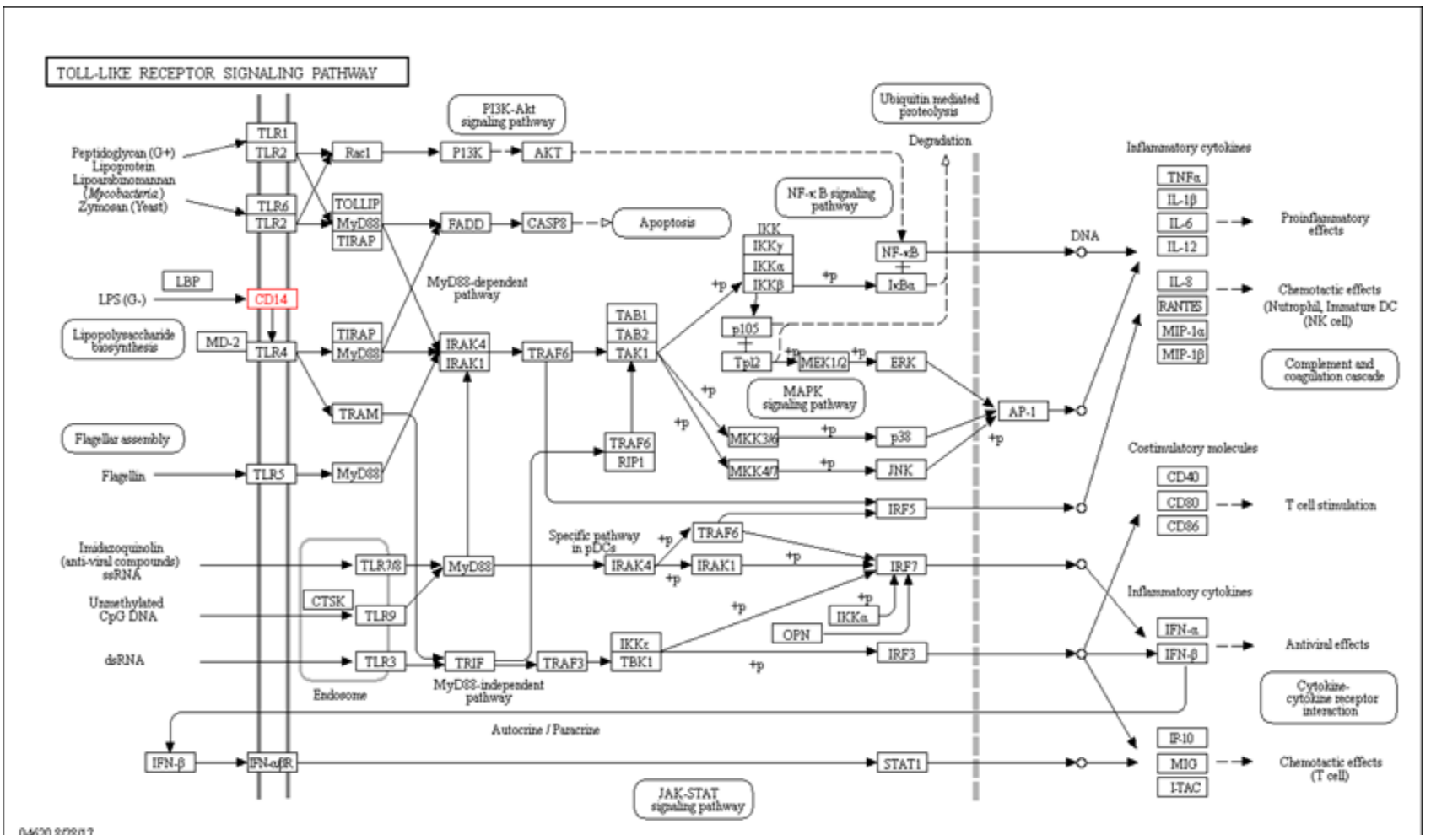

Gambar 3. CD14 sebagai reseptor imun non spesifik

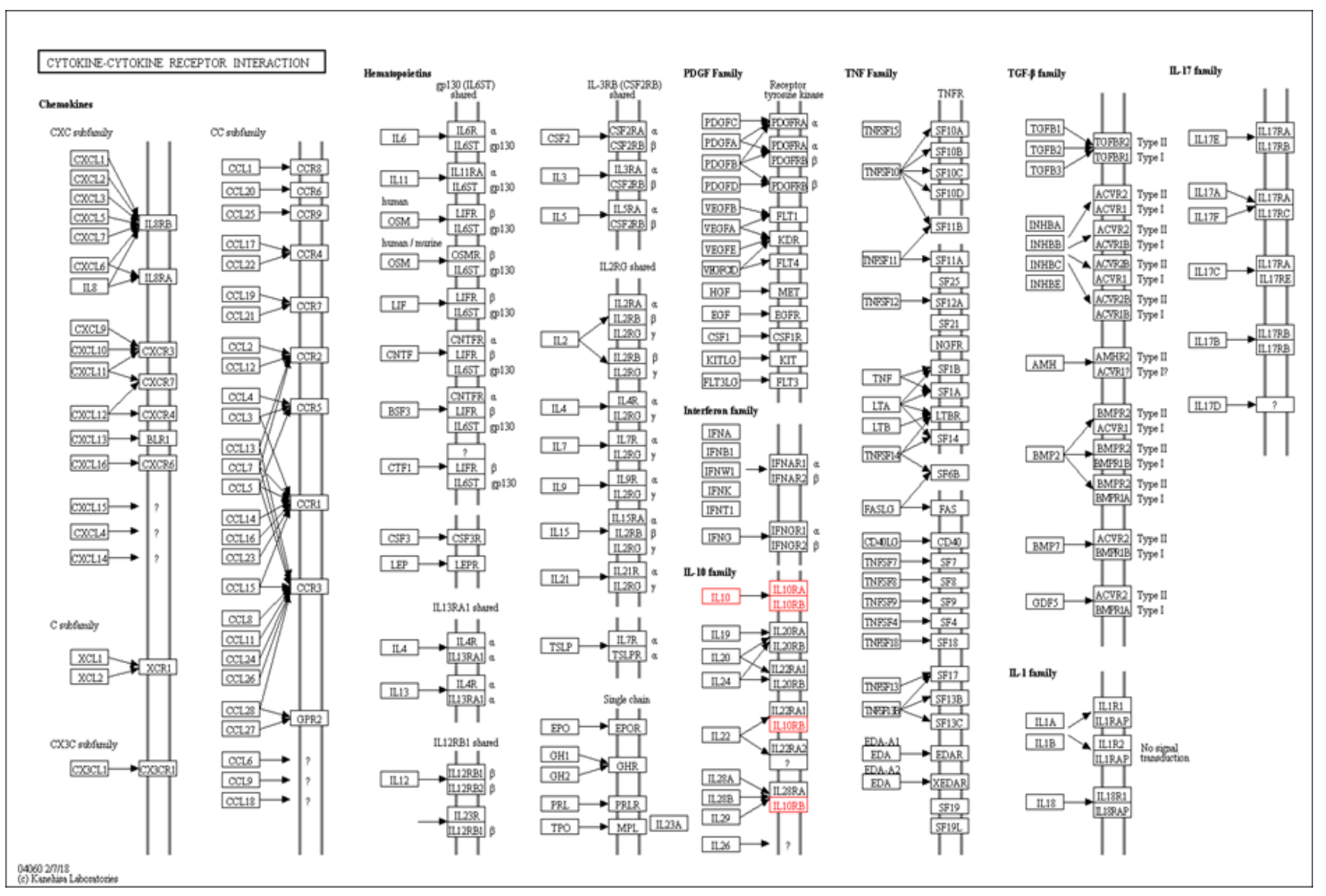

Gambar 4. IL10 sebagai inhibitor imun non spesifik 
polipeptida: dua rantai IL10R1/A yang mengikat ligan dan dua rantai IL-10R2/B yang memulai transduksi sinyal (Gambar 4). Di antara gen yang diaktifkan oleh IL10 adalah SOCS1 dan SOCS3. SOCS1 dikenal sebagai fisiologis utama inhibitor IFN $\gamma$, IL10, dan IL4-induced signal transduction, dan telah ditunjukkan bahwa SOCS1 membungkam sinyal dengan mengikat loop aktivasi dari JAK kinase dan secara fisik menutup situs aktivitas kinase mencegahnya dari memfosforilasi substratnya (Pestka S et al. 2004). Artinya jika sinyal transduksi tidak teraktivasi maka tidak akan ada respon imun untuk menghancurkan patogen penyebab mastitis.

IL10 diketahui sebagai antagonis sitokin dan protein tersebut dapat berikatan dengan reseptor sitokin tetapi tidak dapat mengaktifkan sel dan mencegah aktivitas biologis sitokin. IL10 selular menekan respon Th1 yang efektif terhadap patogen intraselular dan virus. Aktivitas IL10 mengatur aksis Th1-Th2, jika produksi IL10 berlebih maka keseimbangan subset Th1-Th2 akan terganggu dan menyebabkan menurunnya imunitas selular, IL10 akan cenderung sebagai imunosupresif (Baratawidjaja dan Rengganis 2014). IL10 sebagian menghambat induksi kegiatan yang diprakarsai oleh sitokin lain, terutama IFN $\gamma$, IL2, TNF $\alpha$, dan IL4 (Pestka S et al 2004). Ekspresi IL10 yang tinggi pada sapi yang terinfeksi mastitis subklinis menunjukan bahwa respon imun tidak berfungsi dengan baik diduga karena penghambatan sinyal transduksi sitokin oleh produksi IL10 yang berlebih.

\section{KESIMPULAN}

Ekspresi gen mRNA pada sapi sehat dan sapi yang terinfeksi mastitis subklinis menunjukan perbedaan. Ekspresi mRNa gen CD14 menunjukan ekspresi yang tinggi $(\mathrm{P}<0,05)$ pada sapi yang sehat. Ekspresi mRNA gen IL10 menunjukan ekspresi yang tinggi $(\mathrm{P}<0,05)$ pada sapi yang terinfeksi mastitis subklinis. Ekspresi CD14 yang tinggi pada sapi yang sehat mengindikasikan bahwa reseptor imunitas berfungsi dengan baik dalam proses mengenali serangan bakteri penyebab mastitis untuk kemudian dihancurkan melalui serangkaian proses imunitas. Ekspresi IL10 yang tinggi pada sapi yang terinfeksi mastitis subklinis menunjukan bahwa respon imun tidak berfungsi dengan baik diduga karena penghambatan sinyal transduksi sitokin oleh produksi IL10 yang berlebih.

\section{DAFTAR PUSTAKA}

[Kementan] Kementerian Pertanian (ID). 2016. Outlook Susu 2016 Komoditas Pertanian Subsektor Peternakan. Jakarta (ID): Pusat Data dan Sistem Informasi Pertanian Sekretariat Jenderal Kementerian Pertanian.

Abbas AK, Lichtman AH, Pillai S. 2007. Cellular and Molecular Immunology 6th Edition. Philadelphia (US): Elsevier Publisher.

Anri A. 2008. Manual on Mastitis Control. The Project for Improvement of Counter measures on the Productive Diseases on dairy Cattle in Indonesia. Jakarta (ID):
Jica Indonesia Office. ANSCI 308.

Bannerman DD, Paape MJ, Hare WR, Sohn EJ. 2003. Increased levels of LPS-binding protein in bovine blood and milk following bacterial lipopolysaccharide challenge. J Dairy Sci. 86:3128-3137.

Baratawidjaja KG, Rengganis I. 2014. Imunologi Dasar, Edisi Kesebelas. Jakarta (ID): Balai Penerbit Fakultas Kedokteran Indonesia.

Barral NM, Barral A, Brodskyn C, Carvalho EM, Reed SB. 1995. Cytotoxicity in human mucosal and cutaneousleishmaniasis. Parasite Immunol. 17:21-28

Bramley AJ. 1991. Mastitis : Physiology or Pathology. Flem. Vet.J. (62):Suppl.1, 3-11.

Cyktor JC, Turner J. 2011. Interleukin-10 and immunity against prokaryotic and eukaryotic intracellular pathogens. Infection and Immunity. 79(8):2964-2973

Fonseca I, Silva PV, Lange CC, Guimarães MFM. 2009. Expression profile of genes associated with mastitis in dairy cattle. Genet. Mol. Biol. 32: 776-781.

Herlina N, Afiati F, Cahyo AD. 2015. Isolation and identification of Staphylococcus aureus from subclinical infection dairy cattle in Tasikmalaya, West Java. Pros Sem Nas Masy Biodiv Indon. DOI: 10.13057/psnmbi/ $\mathrm{m} 010305$.

Huang JM, Wang XG, Jiang Q, Sun Y, Yang CH, Ju ZH, Hao HS, Wang CF, Zhon JF, Zhu HB. 2016. Identification of CD14 transcript in blood polymorphonuclear neutrophil leukocytes and functional variation in Holsteins. Genetics and Molecular Research. 15 (2): gmr.15027932

Hurley WL, Morin DE. 2000. Mastitis lesson.Lactation Biology. Illionis (US). University of Illionis.

Lindmark MH, Branning C, Alden G, Paulsson M. 2006. Relationship between somatic cell count, individual leukocyte populations and milk components in bovine udder quarter milk. Int Dairy J. 16:717-727

Paape M, Mehrzad J, Zhao X, Detilleux J, Burvenich C. 2002. Defense of the bovine mammary gland by polymorphonuclear neutrophil leukocytes. J Mammary Gland Biol. Neoplasia7:109-121.

Pestka S, Krause CD, Sarkar D, Walter MS, Shi Y, Fisher PB. 2004. Interleukin-10 and related cytokines and receptors. Annu Rev Immunol. 22:929-979.

Quinn PJ, Markey BK, Carter ME, Donnely WJ, Leonard FC. 2002. Veterinary Microbiology and Microbial Disease. Oxford (UK).Blackwell Science Ltd. 63.

Radostits OM, Gay CC, Blood DC, Hinchcliff KW. 2000. Veterinary Medicine. ATextbook of Diseases of Cattle, Sheep, Pigs, Goats and Horses, ninth ed. London (UK). W. B. Saunders pp. 603-660.

Rice DN, Bodman GR. 1997. The Somatic Cell Count and Milk Quality. Cooperative Extension. Institute of Agriculture and Natural Resources. Nebraska (US) University of Nebraska-Linccoln. G 93-1151-A.PP.2-4.

Riollet C, Rainard P, Poutrel B. 2001. Cell subpopulations and cytokine expression in cow milk in response to chronic Staphylococcus aureus infection. J Dairy Sci. 84:1077-1084.

Schroeder JW. 2010. Mastitis Program Control: Bovine 
Mastitis and Milking Management. Extension Service. North Dakota (US). North Dakota State University (NDSU). AS-1129.

Shaulian E, Karin M. 2002. AP-1 as a regulator of cell life and death. Nat Cell Biol ;4:131-6.

Silver DL, Wang N, Vogel S. 2003 Identification of small PDZK1-associated protein. DD96/MAP17. as a regulator of PDZK1 and plasma high density lipoprotein levels. J Biol Chem. 278: 28528-28532.

Sladek Z, Rysanek D. 2006. The role of CD14 during resolution of experimentally induced Staphylococcus aureus and Streptococcus uberis mastitis. Comp Immuno Microbiol Infect Dis. 29: 243-262.

Sudarwanto M, Latif H, Noordin M. 2006. The relationship of the somatic cell counting to sub-clinical mastitis and to improve milk quality. In: Proceedings of the 1st International AAVS Scientific Conference. Jakarta, 1113 July 2006. Bogor (ID): Faculty of Veterinary Medicine, Bogor Agricultural University.

Sudarwanto M. 2009. Mastitis dan kerugian ekonomi yang disebabkannya. Makalah pada TOT JICA The 3rd. Cikole-Lembang, Bandung Barat (ID). 